\title{
Fen Bilimleri Dersinde Tamamlayıcı Ölçme ve Değerlendirme Yaklaşımlarının Tutum ve Başarıya Etkisi
}

\section{The Effect of Complementary Measurement and Assessment Approach on the Attitude and Success in Science and Technology Course}

Öz: Bu araştırmanın amacı, geleneksel ölçme ve değerlendirme yaklaşımlarını destekleyici olarak tamamlayıcı ölçme ve değerlendirme yaklaşımı kullanımının öğrencilerin Fen Bilimleri dersindeki tutum ve başarılarına olan etkisini sınamaktır. Deneysel çalışma hazır gruplar üzerinde yapılmışıtır. Mevcut üç şubeden ikisi kura ile atanmıştır. Araştırmanın çalışma grubunu biri deney $(n=17)$ diğeri kontrol $(n=17)$ grubu olmak üzere iki sınıf oluşturmaktadır. Araştırmada ön-test son-test kontrol gruplu deneysel desen kullanılmıştır. Deney grubuna geleneksel ölçme ve değerlendirme yaklaşımlarını destekleyici olarak tamamlayıcı ölçme ve değerlendirme yaklaşımları, kontrol grubuna ise sadece geleneksel ölçme ve değerlendirme yaklaşımları araştırmacı tarafından uygulanmıştır. Uygulama öncesi deney ve kontrol gruplarına uygulama öncesinde ve sonrasında "Fen Bilgisi Dersi Tutum" ölçeği ile "Akademik Başarı Testi" envanterleri ön test olarak uygulanmıştır. Araştırmadan elde edilen verilerin analizi tek faktörlü kovaryans analizi (ANCOVA) kullanılarak değerlendirilmiştir. Sonuç olarak, geleneksel ölçme ve değerlendirme yaklaşımlarını destekleyici olarak uygulanan tamamlayıcı ölçme ve değerlendirme yaklaşımlarının uygulandığı deney grubundaki öğrenciler ile sadece geleneksel ölçme ve değerlendirme yaklaşımlarının uygulandığı kontrol grubundaki öğrencilerin akademik başarıları ve fen bilgisi dersine yönelik tutumları arasında manidar bir farkın olmadığı saptanmıştır.

Anahtar sözcükler: Fen Bilimleri Başarısı, Fen Bilgisine Yönelik Tutum, Tamamlayıcı Ölçme ve Değerlendirme, Rubrik

\begin{abstract}
The purpose of this research is to examine the effect of complementary measurement and assessment approach supporting traditional measurement and assessment approaches, on the attitude and success in Science and Technology course. The experimental study was made on ready groups. Two classes out of three were assigned by drawing. The study group of the research consists of two classes, one of which is the experiment group $(n=17)$ and the other is the control group $(n=17)$. In the research, experimental pattern with pre-test post-test control group was employed. Complementary measurement and assessment approaches supporting traditional measurement and assessment approaches were applied to experiment group and only traditional measurement and assessment approaches were applied to control group by the researcher. "Science and Technology Course Attitude" and "Academic Success Test" inventories were applied to experiment and control groups as pretest before application. The analysis of the data obtained from the study was assessed using the one factor covariance analysis (ANCOVA). As a result, there was no significant difference observed between the Science and Technology Course attitude and academic success of the students both in the experiment group and in control group.
\end{abstract}

Keywords: Science and Technology Success, Attitude Towards Science and Technology, Complementary Measurement and Assessment, Rubric

\footnotetext{
* Doktora Öğr., Kastamonu Üniversitesi, Eğitim Fakültesi, İlköğretim Bölümü, Kastamonu. sekerrfatih@gmail.com

**Doç. Dr., Akdeniz Üniversitesi, Eğitim Fakültesi, İlköğretim Bölümü, Antalya. hsert@akdeniz.edu.tr
} 
İnsanoğlu var olduğu günden itibaren sürekli çevresinde olup bitenleri gözlemlemiş, hem kendi varlık nedenlerini hem de olayların oluş nedenlerini açıklama gayretine girmiştir (Çepni et al. 2009). Bunu takiben sürekli bir bilgi artışı olmuş, beraberinde yeni teknolojiler üretilmiş ve geliştirilmiştir (Tan \& Temiz 2003). Bütün gelişme ve değişmeler doğrultusunda ülkeler, mevcut durumlarını daha üst seviyeye taşımak için eğitime büyük yatırımlar yapmaktadır. Eğitim, bir ülkenin siyasi ve sosyal alanlarda ileriye dönük hedeflerinin gerçekleştirilmesinde anahtar bir rol oynamaktadır. Bir ülkede verilen eğitimin niteliği ne kadar yüksek ise o ülkede gelişmişlik seviyesi de o denli yüksektir (Yıldırım 2006).

Eğitim, "insanlı̆̆ın kişiliğini besleme süreci" ile "insan sermayesine yapılan yatırım" olarak kabul edilmektedir. En genel tanımıla "istendik davranış oluşturma ya da istendik davranış değiştirme süreci" olarak tanımlanan eğitim, toplumun süzgeçten geçirilmiş değerlerinin, ahlak standartlarının bilgi ve beceri birikimlerinin yeni nesillere aktarılması ile ilgilidir (Senemoğlu 2011). Eğitimin en sonunda ulaşmak istediği hedef, bireylerin yaşam kalitesinin yükseltilmesi, yaşam için gerekli bilgi ve becerilerin kazandırılması, yeteneklerin ve tutumların geliştirilmesi olarak ifade edilir (Bloom 1979). Bu hedefler doğrultusunda bireylerin nitelikli olarak yetiştirilmesi eğitime, eğitimin istenilen düzeyde olması ise etkili eğitim programlarının oluşturulmasına bağlıdır (Arslan-Cansever 2009). Eğitim programları durağan değildir yani eğitim programları çağın gereksinimlerine uygun olarak geliştirilir (Demirel 2011).

Türkiye'de fen programı gelişen dinamikler göz önünde bulundurularak değiştirilmiştir. 2004 yılı öncesinde uygulanan fen programında daha çok davranışçı yaklaşım ağır basmış, 2004 yılında yapılandırmacı yaklaşıma geçilmiş ve 2013 yılında yapılandırmacı yaklaşımı da temel alan araştırma ve sorgulamaya dayalı fen programı benimsenmiştir (MEB 2013). Yapılandırmacı yaklaşıma geçilmeden önce geleneksel öğretme yöntemleri benimsenmekteydi. Bu dönemde birey, yetkili otoritelerin belirlediği yeterlilikleri yine onların belirlediği yöntemlerle kazanmaktaydı (Choi et al. 2011). Geleneksel öğretme yöntemleri uygulanan sınıflarda öğrencilerin kendi öğrenme süreçlerinin sorumluluğunu taşıyamayacak kadar edilgen olmaları ve bağımsız düşünme firsatı verilmemesi öğrencilerin özgüven, güdü, sosyallik ve yaratıc1lıklarını yok edip, onların üst düzey düşünme becerileri kazanmalarına ket vurmaktadır (El-Koumy 2011; Ün-Açıkgöz 2011). Geleneksel öğretimin bu şekilde toplumsal gereksinimlere ters düşmesi ve çağı yakalayan bireyler geliştirmek amacıyla 2004 ve 2013 yıllarında yapılan değişiklikler ile beraber öğretmen merkezli anlayıştan öğrenci merkezli anlayışa geçilmiştir (Aşkar et al. 2005; MEB 2013). Öğrenciyi merkeze alan yapılandırmacı eğitim ortamları, bireylerin çevreleriyle daha fazla etkileşimde bulunmasına, kendi öğrenmelerinden sorumlu olmasına, üst düzey düşünme becerilerinin gelişmesine ve bilginin transfer edilebilmesine firsat verecek şekilde oluşturulmalıdır. Bu tür eğitsel ortamlar sayesinde bireyler, zihinlerinde daha önce yapılandırdıkları bilgilerin doğruluğunu sınama, yanlışlarını düzeltme ve hatta önceki bilgilerinden vazgeçerek yerine yenilerini koyma firsatı elde ederler (Perkins 1999; Gültekin et al. 2007). Yapılandırmacı yaklaşımın öngördüğü öğrenci merkezli anlayışa geçiş süreci, programın önemli bir uygulaması olan ölçme ve değerlendirme sürecine dikkat çekmiştir. Bu durum ölçme değerlendirme boyutunda değişikliğe gitme zorunluluğunu ortaya çıkarmış ve bu boyutta tamamlayıcı değerlendirme yaklaşımları esas alınmıştır (Lawrenz et al. 2001; Erdin 2010). Fen Bilimleri 2004 programından önce öğrenciler geleneksel ölçme ve değerlendirme yaklaşımları ile değerlendiriliyordu. Bu yöntemlerle öğrenci başarısının değerlendirilmesi, genellikle öğretim sürecinden ayrı ve daha çok ürüne ağırlık verecek bir şekilde ele alınmakta; bu amaçla daha çok seçmeli ve kısa cevaplı testlerle, yazılı ve sözlü yoklamalara önem verilmekteydi (Gelbal \& Kelecioğlu 2007; Kavaliauskienè et al. 2007). Bu ölçme ve değerlendirme anlayışında, öğrencileri başarılı ya da başarısız olarak sınıflandırmak yeterli olurken öğrenci hangi kriterlere göre 
değerlendirileceğini bilmemekte, kendi durumunun farkında olamamakta, ezberleyerek kolaylıkla yapabileceği ya da çok az bir çaba ile üstesinden gelebileceği soruları içeren sınavlarla karşı karşıya kalmaktaydı. Bunun sonucunda da öğrenciler düşünmeyi, tartışmayı, yorum yapmay1 ve eleştirmeyi önemsemeyerek büyümekteydi (Anderson 1998; Çiftçi 2010). Ayrıca fen öğretiminin amaçlarından olan öğrenciye bilgiye ulaşma ve bilgiyi kullanma yollarının, bilimsel süreç becerilerinin ve fen okuryazarlığının kazandırılıp kazandırılmadığı da geleneksel ölçme ve değerlendirme yaklaşımlarıyla test edilememektedir (Lederman et al. 2002). Geleneksel sistem ögrenciyi ölçme ve değerlendirme sürecinde pasif tutmakta ve ürün veya süreci değerlendirmede öğrencilere firsat tanımamakta, onları sürecin dışında tutmaktadır (Baniabdelrahman 2010). Ülkeler fen ve matematik alanlarındaki başarılarını, gelişimlerini görebilmek için TIMSS (Trends in International Mathematics and Science Study), PISA (Programme for International Student Assessment) ve PIRLS (Progress in International Reading Literacy Study) gibi uluslararas1 karşılaştırma sınavlarına katılmaktadır. Bu sınavlar bireylerin sadece bilimsel bilgilerinin değil üst düzey düşünme becerilerini de ölçmektedir. Türkiye'deki öğrencilerin uluslararası düzeyde yapılan bu sınavlarda fen başarılarının düşük seviyede olduğu tespit edilmiştir (Uzun et al. 2010).

Geleneksel sistemin aksine, öğrenmede bireysel farklılıkları dikkate alan, bireyin kendine özgü özelliklerini ön plana çıkararak herkesin sahip olduğu bilgilerle yeni aldığı bilgileri kendine özgü biçimde yapılandırdığını öne süren, bu nedenle de öğretim yöntemleri ve tekniklerinin mümkün olduğunca çeşitlendirilmesi gerektiğini vurgulayan yeni öğrenci merkezli yaklaşımda, ölçme ve değerlendirmede de öğrencilere bilgi, beceri ve tutumlarını sergileyebilecekleri değerlendirme firsatları sunulmasının gerekliliği vurgulanmaktadır (Chang \& Wu 2011; Poon et al. 2009).

$\mathrm{Bu}$ araştırmada, Fen Bilimleri, "IŞık" ünitesinde, geleneksel ölçme ve değerlendirme yaklaşımlarını destekleyici nitelikteki tamamlayıcı ölçme ve değerlendirme yaklaşımlarına göre düzenlenen ve yürütülen bir öğretim sürecinin, 7. sınıf öğrencilerinin fen bilgisi dersine karş1 tutum ile fen bilimleri dersi başarısına etkisine belirlenmek amaçlanmıştır. Bu amaca yönelik olarak alt problemler aşağıda belirtilmiş̧ir:

Fen bilimleri dersinde geleneksel ölçme ve değerlendirme yaklaşımlarını destekleyici nitelikteki tamamlayıcı ölçme ve değerlendirme yaklaşımlarının kullanıldığı deney grubu ile geleneksel ölçme değerlendirme yaklaşımının kullanıldığı kontrol grubu öğrencilerinin, uygulama öncesinde ve sonrasında, fen bilgisi dersi tutum ölçeğinden aldıkları puanları arasında manidar bir fark var midır?

Fen bilimleri dersinde geleneksel ölçme ve değerlendirme yaklaşımlarını destekleyici nitelikteki tamamlayıcı ölçme ve değerlendirme yaklaşımlarının kullanıldığı deney grubu ile geleneksel ölçme değerlendirme yaklaşımlarının kullanıldığı kontrol grubu öğrencilerinin, uygulama öncesinde ve sonrasında, akademik başarı testinden aldıkları puanlar arasında manidar bir fark var midır?

\section{Yöntem}

\section{Araștırma Modeli}

Bu araştırma, 7. sınıf Fen Bilimleri Dersi Öğretim Programı'ndaki hedefleri gerçekleştirmeye yönelik olarak "Tamamlayıcı Ölçme ve Değerlendirme" yaklaşımlarını kullanımının duyuşsal özelliklere etkisini ve öğretme-öğrenme sürecindeki hedeflenen davranışları kazandırmadaki etkinliğini kontrollü olarak belirlemeye çalışması yönüyle deneysel niteliktedir. Araştırmada, ön-test son-test denkleştirilmemiş desen kullanılmıştır. Deneme süreci iki grup üzerinden gerçekleştirilmiştir. Gruplar rastgele yolla deney ve kontrol grubu olarak atanmıştır. Uygulama 
öncesinde grupların bağımlı değişkenlerinin bilinmesi, değişimin ölçülmesine ve test edilmesine olanak tanımasını sağlayarak, modelin kullanılabilirliğini arttırmaktadır (Büyüköztürk et al. 2010).

Çalışmanın bağımlı değişkenlerini fen bilgisi dersine karşı tutum ile fen bilimleri dersi başarısı oluşturmaktadır. Araştırmanın bağımsız değişkeni uygulanan değerlendirme yaklaşımıdır. Araştırmada etkisi incelenen işlem tamamlayıcı ölçme ve değerlendirme yaklaşımlarıdır. Bu işlem, deney grubunda geleneksel ölçme ve değerlendirme yaklaşımlarını destekleyici bir uygulama olarak verilirken, kontrol grubunda sadece geleneksel ölçme ve değerlendirme yaklaşımına yer verilmiş tamamlayıcı ölçme ve değerlendirme yaklaşımlarına yer verilmemiştir. Çalışmaya katılacak öğrencilerin fen bilimleri dersine karşı tutumları ile fen bilimleri başarıları hem deney öncesinde hem de deney sonrasında ölçülmüştür.

Deney ve kontrol grubunda öğretim yöntem ve teknikleri araştırmacı tarafından uygulanmıştır. Deneysel işlem süreci öncesinde ve sonrasında deney ve kontrol gruplarının fen bilgisi dersine karşı tutumları ile fen bilimleri dersi başarıları ölçülmüş̧ür. Bu araştırmada öğrenci başarıları bilişsel davranışları tanımlamaktadır.

Bilişsel özellikler; bilgi, beceri ve yetenek olarak gruplandırılabilir. Bilgi ve beceriler çoktan seçmeli test ile ölçülebilirken yetenek düzeyindeki davranışlar ölçülmesi sınırlıdır. Yetenek düzeyindeki davranışların ölçülmesi; performans görevleri olarak tanımlanabilecek açık uçlu soruları içeren öğrenme görevleri ile gerçekleştirilmiştir (Krathwohl et al. 1956; Britton 2011, 1617).

\section{Çalışma Grubu}

Antalya ili Muratpaşa ilçesinde özel okulda bulunan yedinci sınıf şubeleri üzerinden yürütülmüştür. Yedinci sınıf düzeyindeki üç şubeden yansız atama yolu ile biri deney (7-B sınıfi) diğeri kontrol (7-C sınıfi) grubu belirlenmiştir. Çalışma grubunu öğrenimlerine devam eden deney $(n=17)$ ve kontrol $(n=17)$ grubu olmak üzere 34 öğrenci oluşturmaktadır. Toplam 34 öğrenci ile yürütülen çalışmalar esnasında bir öğrenci devamsızlığı sebebiyle değerlendirme kapsamına alınmamıştır ve çalışma grubuna ait analizler 16'sı deney ve 17'si kontrol olmak üzere toplamda 33 öğrenci ile yürütülmüştür.

Deney ve kontrol gruplarının, çalışmanın başlamasından önce akademik başarı açısından denkliklerini saptamak amaciyla kanıt toplama yoluna gidilmiştir. Bu nedenle deney ve kontrol gruplarını oluşturan öğrencilerin bir önceki döneme ait karne notları esas alınarak, ortalamalar arası fark t-testi kullanılarak tespit edilmiştir. Analiz sonuçları Tablo 1'de sunulmuştur.

Tablo 1. Deney ve Kontrol Grubu Öğrencilerinin Karne Notu Ortalamaları Bağımsız Gruplarda t-Testi

\begin{tabular}{|l|l|l|l|l|l|l|}
\hline Grup & N & \multicolumn{1}{|c|}{} & Standart Sapma & sd & t & P \\
\hline Kontrol & 17 & 87.9 & 9.98 & 31.0 & 0.44 & .67 \\
\hline Deney & 16 & 89.3 & 9.70 & 30.8 & & \\
\hline$p>.05$ & &
\end{tabular}

Tablo 1'de görüleceği gibi deney grubundaki öğrenciler ile kontrol grubundaki öğrencilerin karne not ortalaması arasında manidar bir fark olmadığı gözlenmiştir ( $p>.05)$. Buna göre deneysel işlem sürecine başlamadan önce akademik başarı açısından deney ve kontrol grupları arasında başarı yönünden manidar bir farkın olmadığı sonucuna varılabilir. 


\section{Veri Toplama Araçları}

Araştırmanın hipotezlerini test etmek amacıyla; öğrencilerin "Işılk" ünitesi akademik başarılarını ölçmek için araştırmacı tarafindan geliştirilen ve Testin KR20 güvenirlik katsayısı 0.95 olarak hesaplanan "Akademik Başarı Testi" ile fen bilimleri dersine yönelik tutumlarını ölçmek için Oğuz (2002) tarafindan geliştirilen ve Cronbach alpha katsayısı 0.85 olarak hesaplanan "Fen Bilgisi Dersi Tutum Ölçeği” veri toplama aracı olarak uygulanmıştır. Çalışmada performans görevleri süreci sonunda deney grubu öğrencilerinin performans görevlerini, kendilerini ve akranlarını değerlendirme firsatı sunan ve süreç değerlendirmeyi içine alan grup öz değerlendirme formu, grup akran değerlendirme formu ve analitik rubrik puanlama formu da uygulanmıştır.

\section{Verilerin Elde Edilmesi ve Uygulama}

Uygulama öncesinde kura yöntemi ile seçilen deney grubu ile bir ön çalışma yapılmıştır. Deney grubu öğrencilerinin bir önceki karne notları esas alınarak oluşturulan başarı listesinde öğrencilerin not ortalaması en yüksek olandan en düşük olana doğru sıralamıştır. İlk dört öğrenciye sırasıyla A, B, C, D harfleri verilmiştir. Bundan sonra gelen dört öğrenciye ise harfler sondan başlayarak verilmiştir. Aynı işlem listenin sonundan yukarı doğru yapılmıştır. Bu işlemler ile yaklaşık olarak birbirine denk 4'er kişilik heterojen gruplar oluşturulmuştur.

Rubriklerle değerlendirme süreci olarak yedinci sınıf "Işıl $k$ " ünitesi başlangıcında ilgili üniteyi içeren performans görevleri katılımcılara verilmiştir. Üniteye başlamadan önce araştırmacı tarafından uzman görüşleri alınarak analitik rubrik puanlama formu oluşturulmuş ve analitik rubrik puanlama formu öğrencilere dağıtılmıştır. Performans görevlerine ilişkin öğrencilerin sonuçlarının raporlaştırılması için araştırma raporları ile bu raporları nasıl dolduracaklarına ilişkin yönerge öğrencilere örnek olarak gösterilmiştir. Böylece öğrencilere süreç sonunda nasıl puan alacakları konusunda bilgilendirme yapılmıştır. Süreç sonunda öğrencilerin hazırlamış oldukları raporlar ve analitik rubrik araştırmacı ile birlikte 2 fen bilimleri tarafından kodlanmıştır. Ayrıca süreçte öğrencilere kendilerini, gruplarını ve akranlarını değerlendirme firsatı veren değerlendirme formları da dağıtılmıştır.

Sürece başlamadan önce, her iki grubun denkliklerini belirlemek amaciyla uygulanan Fen Bilimleri Dersi Akademik Başarı Testleri başarıyı belirlemede, Oğuz (2002) tarafından geliştirilen "Fen Bilgisi Dersi Tutum Ölçeği" ise fen dersine karşı tutumu belirlemede ölçüt olarak kabul edilerek ön test puanları elde edilmiştir.

Süreç içerisinde fen bilimleri dersine ilişkin deneysel işlemin sadece okul içinde yapılmasına özen gösterilmiştir. Bunun için araştırmada deney grubu öğrenci çalışmalarının uygulamaya konu olan okulda fen bilimleri laboratuvarı, kütüphane ile etüt merkezinde sürdürülmesi sağlanmıştır. Etüt merkezinde, deney grubu öğrencileri kendilerine dağıtılan performans görevlerine ilişkin araştırmalarını, bilgi paylaşımını ve grup içerisindeki çalışmalarını gerçekleşmiştir. Fen bilimleri laboratuvarında ise öğrenciler daha çok performansa yönelik çalışmalarda bulunmuştur.

Deney grubu öğrencileri 4'er kişiden oluşan 4 gruba ayrılmıştır. Performans görevlerine ilişkin uygulamalar tamamlandıktan sonra öğrencilere performans görevleri sürecine ilişkin olarak "Işıl "ünitesine ait dereceli puanlama anahtarı dağıtılmış ve kendilerinden süreci de göz önünde bulundurarak puan vermeleri istenmiştir. Öğrenciler ayrıca süreç içerisinde kendilerini, gruplarını ve akranlarını da grup öz değerlendirme formu ve grup akran değerlendirme formu ile değerlendirmiştir.

Deney ve kontrol grubu olarak belirlenen her iki sınıfta ders işlenişi araştırmacı tarafindan gerçekleştirilmiştir. Bu sürece ilişkin kontrol grubunda genellikle soru-cevap yönteminin benim- 
sendiği söylenebilir. Yine kontrol grubunda derslerin işlenişine ilişkin, bir önceki konunun tekrarı yapılmış, süreçte her öğrencinin etkin olması sorularla sağlanmaya çalışılmıştır. Deney grubunda ise öğrencilerin sorduğu bazı sorular yanıtlanmış diğer sorularda ise öğrenciler daha çok araştırmaya teşvik edilmiştir. Deney grubunda sadece derse ait kritik noktalarda öğrencilere etki edilmiş, kontrol grubunda ise geleneksel bir şekilde anlatıma devam edilmiştir.

Süreç sonunda ise deney grubu ve kontrol grubuna başarı testleri ile fen bilgisi dersi tutum ölçeği uygulanarak son test puanları elde edilmiştir.

\section{Verilerin Analizi}

Amaca uygun olarak hipotezi test etmek için SPSS 16.0 paket programında yer alan istatistik analizleri kullanılmıştır. Büyük gruplara ait puanların karşılaştırılmasında toplanan verilerin normal dağılıma yakın dağılım gösterdikleri kabul edilir ve buna göre parametrik testler seçilebilir. Dağılımın normal dağılımdan aşırı sapma göstermediği şeklinde bir varsayımı sürmek için grubun 30 ve daha üstü olması gerekliliği vurgulanmaktadır (Büyüköztürk 2010). Fakat sosyal bilimler için pek çok araştırma küçük gruplar üzerinde yapılmaktadır. Literatürde alt gruplarının her birinin büyüklüğünün 15 ve daha yüksek olması durumunda parametrik bir test kullanılmasının analizde herhangi bir sapmaya yol açmayacağına ilişkin incelemeler yer almaktadır (Büyüköztürk 2010). Bu nedenle araştırmada, deney ve kontrol grubundaki katılımcı verilerinin normal dağılıp dağılmadığ 1 Kolmogorov-Smirnov testi ile belirlenmiştir. Çalışmada tüm analizler için güven aralığ $\% 95$, anlamlılık $\mathrm{p}=.05$ düzeyi dikkate alınarak yapılmış ve bulgular değerlendirilmiştir. Araştırmanın alt problemlerinin test edilmesinde parametrik testler kullanılmıştır.

Araştırmanın iki alt problemine yanıt aranmıştır. Araştırmanın birinci ve ikinci problemlerinde ön test ve son test uygulanmıştır. Bu testler sonucunda deneysel işlemin etkili olup olmadığ1 iki grubun kontrol gruplu ön test-son test puanlarının farkları belirlenmiştir. $\mathrm{Bu}$ karşılaştırmada alınan iki ortalama arasındaki farkın manidar olup olmadığı, tek faktörlü kovaryans analizi (one factor ANCOVA) ile test edilmiştir. Kovaryans analizinin amacı, bir araştırmada etkisi test edilen bir faktörün ya da faktörlerin dışında, bağımlı değişken ile ilişkisi olan bir başka değişkenin veya değişkenlerin istatistiksel olarak kontrol edilmesini sağlamaktır. Böylece kovaryans analizi hata varyansı azalarak daha etkili bir istatistiksel güç sağlar. Araştırmada ön testin son test puanına olan etkisi ANCOVA kullanılarak kontrol edilmiştir. Burada ön test puanları ortak değişken olmak üzere analize dahil edilmiştir. Sonuçta grupların ön teste göre düzeltilmiş son test ortalama puanları karşılaştırılmıştır (Büyüköztürk 2010).

\section{Bulgular ve Yorum}

Araştırmanın birinci alt problemine yönelik olarak elde edilen tutum ölçeğindeki puanların kovaryans analizi (ANCOVA) için verilerin normal dağılım göstermesi gerekmektedir. Bu yüzden deney ve kontrol gruplarının fen bilgisi dersi tutum ölçeğinden aldıkları puanların normal dağılım gösterip göstermediğini belirlemek için Kolmogorov-Smirnov normallik testi yapılmıştır. Normallik testi için deney ve kontrol grupları arasında $\alpha=.05$ manidarlık düzeyinde bir farkın olup olmadığına bakılmıştır. Yapılan Kolmogorov-Smirnov normallik testi sonuçları Tablo 2'de verilmiştir. 
Tablo 2. Deney ve Kontrol Gruplarına Ait Tutum Puanlarına İlişkin Ölçümlerin Betimsel İstatistikleri ve Kolmogorov-Simirnov Z ile Normallik Testi

\begin{tabular}{|l|l|l|l|l|l|l|}
\hline \multirow{2}{*}{ Gruplar } & Ölçümler & $\begin{array}{l}\text { Kişi Sayısı } \\
(\mathbf{n})\end{array}$ & Ortalama & $\begin{array}{l}\text { Standart } \\
\text { Sapma }\end{array}$ & K-S(z) & $\begin{array}{l}\text { Anlamlılık } \\
\text { Düzeyi(p) }\end{array}$ \\
\hline \multirow{2}{*}{ Deney } & Ön test & 16 & 3.73 & 0.94 & 0.78 & .57 \\
\cline { 2 - 7 } & Son test & 16 & 3.55 & 0.87 & 0.74 & .64 \\
\hline \multirow{2}{*}{ Kontrol } & Ön test & 17 & 3.57 & 0.89 & 0.63 & .82 \\
\cline { 2 - 7 } & Son test & 17 & 3.37 & 0.73 & 0.88 & .43 \\
\hline p>.05 & & & & &
\end{tabular}

Tablo 2 incelendiğinde deney ve kontrol gruplarına ait fen bilgisi dersi tutum puanlarından elde edilen $\mathrm{K}-\mathrm{S}(\mathrm{z})$ analizi sonucunda deney grubu öğrencilerinin tutum ön test ile son test değişkenlerinin $(\mathrm{K}-\mathrm{S}(\mathrm{z})=0.78 ; \mathrm{p}>.05, \mathrm{~K}-\mathrm{S}(\mathrm{z})=0.74 ; \mathrm{p}>.05)$ normal dağılım gösterdiği belirlenmiştir. Aynı şekilde kontrol grubu öğrencilerinin ait tutum ön test ile son test değişkenlerinin $(\mathrm{K}-\mathrm{S}(\mathrm{z})=0.63$; $\mathrm{p}>.05, \mathrm{~K}-\mathrm{S}(\mathrm{z})=0.88 ; \mathrm{p}>.05)$ normal dağılım gösterdiği belirlenmiştir. Buna göre deney ve kontrol gruplarının tutum ön test ile son test ölçümlerinin normal dağılım gösterdiği, dolayısıyla kovaryans analizinin varsayımını sağladığı görülmektedir. Fen Bilgisi dersi tutum ölçeğine ilişkin betimsel istatistikler Tablo 3'te, ANCOVA sonuçları Tablo 4'te verilmiştir.

Tablo 3. Betimleyici İstatistikler, Bağımlı Değişken: Fen Bilgisi Dersi Tutum Ölçeği Son Test

\begin{tabular}{|l|l|l|l|l|}
\hline Grup & $\begin{array}{l}\text { Kişi Sayısı } \\
(\mathbf{n})\end{array}$ & $\begin{array}{l}\text { Ön Test } \\
\text { Ortalama }\end{array}$ & $\begin{array}{l}\text { Son Test } \\
\text { Ortalama }\end{array}$ & $\begin{array}{l}\text { Düzeltilmiş Son Test } \\
\text { Ortalama }\end{array}$ \\
\hline Deney & 16 & 3.73 & 3.56 & 3.53 \\
\hline Kontrol & 17 & 3.57 & 3.37 & 3.40 \\
\hline
\end{tabular}

Tablo 3 incelendiğinde ön teste göre düzeltilmiş fen bilgisi dersi tutum ölçeği son test ortalama puanı deney grubu için $\bar{X}=3.53$, kontrol grubu için $\bar{X}=3.40$ 'tır.

Tablo 4. Fen Bilgisi Dersi "Tutum" Ön Test Puanlarına Göre Düzeltilmiş "Tutum" Son Test Puanlarının Gruba Göre ANCOVA Sonuçları

\begin{tabular}{|l|l|l|l|l|l|}
\hline Varyansın Kaynağı & $\begin{array}{l}\text { Kareler } \\
\text { Toplamı }\end{array}$ & $\begin{array}{l}\text { Serbestlik } \\
\text { Derecesi }\end{array}$ & $\begin{array}{l}\text { Kareler } \\
\text { Ortalama }\end{array}$ & F & $\begin{array}{l}\text { Anlamlılık } \\
\text { Düzeyi (p) }\end{array}$ \\
\hline Tutum Ön Test & 2.32 & 1 & 2.31 & 3.87 & .06 \\
\hline Grup (Deney ve Kontrol) & 0.18 & 1 & 0.18 & 0.31 & .58 \\
\cline { 1 - 3 } Hata & 17.3 & 29 & 0.60 & & \\
\cline { 1 - 3 } Toplam & 20.2 & 32 & & & \\
\cline { 1 - 3 }$>05$ & & &
\end{tabular}

Tablo 4 incelendiğinde, deney ve kontrol grubunun ön test puanlarına göre düzeltilmiş tutum ölçeği son testi ortalamaları arasında manidar bir farkın olmadığ bulunmuştur $[F(1.29)=0.31$, $\mathrm{p}>$.05]. Bu bulguya göre geleneksel ölçme ve değerlendirme ile tamamlayıcı ölçme ve değerlendirme yaklaşımlarının uygulandığı deney grubu öğrencilerinin tutum ölçeği düzeltilmiş son test puanları ile sadece geleneksel ölçme ve değerlendirme yaklaşımlarının uygulandığı kontrol grubu öğrencilerinin tutum ölçeği düzeltilmiş son test puanları arasında manidar bir farkın olmayışı, tamamlayıcı ölçme ve değerlendirme yaklaşımlarının tutum üzerinde manidar etkisinin olmadığını göstermektedir. 
Araştırmanın ikinci alt problemine yönelik fen bilimleri dersi “Akademik Başarı Testi”nden aldıkları puanlar tek faktörlü kovaryans analizi (ANCOVA) ile karşılaştırılmıştır. Araştırmada elde edilen verilerin kovaryans analizi (ANCOVA) için verilerin normal dağılım göstermesi gerekmektedir. Deney ve kontrol gruplarının "Akademik Başarı Testi"nden aldıkları puanların normal dağılım gösterip göstermediğini belirlemek için Kolmogorov-Smirnov normallik testi yapılmıştır. Normallik testi için deney ve kontrol grupları arasında $\alpha=.05$ manidarlık düzeyinde bir farkın olup olmadığına bakılmıştır. Yapılan Kolmogorov-Smirnov normallik testi sonuçları Tablo 5 'te verilmiştir.

Tablo 5. Deney ve Kontrol Gruplarına Ait Akademik Başarı Testi Puanlarına İlişkin Ölçümlerin Betimsel İstatistikleri ve Kolmogorov-Simirnov Z ile Normallik Testi

\begin{tabular}{|l|l|l|l|l|l|l|}
\hline \multirow{2}{*}{ Gruplar } & Ölçümler & $\begin{array}{l}\text { Kişi } \\
\text { Sayısı } \\
\text { (n) }\end{array}$ & Ortalama & $\begin{array}{l}\text { Standart } \\
\text { Sapma }\end{array}$ & K-S(z) & $\begin{array}{l}\text { Anlamlılık } \\
\text { Düzeyi(p) }\end{array}$ \\
\hline \multirow{2}{*}{ Deney } & Ön test & 16 & 6.94 & 2.59 & 0.49 & .97 \\
\cline { 2 - 8 } & Son test & 16 & 11.1 & 3.91 & 0.80 & .55 \\
\hline \multirow{2}{*}{ Kontrol } & Ön test & 17 & 8.12 & 2.69 & 0.57 & .91 \\
\cline { 2 - 8 } & Son test & 17 & 11.2 & 2.60 & 0.60 & .87 \\
\hline
\end{tabular}

$\mathrm{p}>.05$

Tablo 5 incelendiğinde deney ve kontrol gruplarının Akademik Başarı Testi puanlarından elde edilen K-S(z) analizi sonucunda deney grubu öğrencilerinin "Akademik Başarı Testi" ön test ile son test değişkenlerinin $(\mathrm{K}-\mathrm{S}(\mathrm{z})=0.49 ; \mathrm{p}>.05, \mathrm{~K}-\mathrm{S}(\mathrm{z})=0.80 ; \mathrm{p}>.05)$ normal dağılım gösterdiği belirlenmiştir. Aynı şekilde kontrol grubu öğrencilerinin başarı testi ön test ile son test değişkenlerinin $(\mathrm{K}-\mathrm{S}(\mathrm{z})=0.57 ; \mathrm{p}>.05, \mathrm{~K}-\mathrm{S}(\mathrm{z})=0.60 ; \mathrm{p}>.05)$ normal dağılım gösterdiği belirlenmiştir. Buna göre deney ve kontrol gruplarının "Akademik Başarı Testi" ön test ile son test ölçümlerinin normal dağılım sağladığı, dolayısıyla kovaryans analizinin varsayımını sağladığı görülmektedir. Deney ve kontrol gruplarının başarı puanlarının normal dağılıp dağılmadığı ile başarı puanları yönünden $\alpha=.05$ manidarlık düzeyinde bir farkın olup olmadığına bakılmıştır. "Işsık" ünitesine ilişkin akademik başarı ile ilgili betimsel istatistikler Tablo 6' da, ANCOVA sonuçları Tablo 7'de verilmiştir.

Tablo 6. Betimleyici İstatistikler, Bağımlı Değişken: Akademik Başarı Testi Son Test

\begin{tabular}{|l|l|l|l|l|}
\hline Grup & $\begin{array}{l}\text { Kişi } \\
\text { Sayısı }\end{array}$ & Ön Test Ortalama & Son Test Ortalama & $\begin{array}{l}\text { Düzeltilmiş Son Test } \\
\text { Ortalama }\end{array}$ \\
\hline Deney & 16 & 6.94 & 11.1 & 11.3 \\
\hline Kontrol & 17 & 8.12 & 11.2 & 11.0 \\
\hline
\end{tabular}

Tablo 6 incelendiğinde ön teste göre düzeltilmiş akademik başarı testi son test ortalama puanı deney grubu için $\bar{X}=11.3$, kontrol grubu için $\bar{X}=11.0$ 'dir.

Tablo 7. Akademik Başarı Testi Ön Test Puanlarına Göre Düzeltilmiş Son Test Puanlarının Gruba Göre ANCOVA Sonuçları

\begin{tabular}{|l|l|l|l|l|l|}
\hline Varyansın Kaynağı & $\begin{array}{l}\text { Kareler } \\
\text { Toplamı }\end{array}$ & $\begin{array}{l}\text { Serbestlik } \\
\text { Derecesi }\end{array}$ & $\begin{array}{l}\text { Kareler } \\
\text { Ortalama }\end{array}$ & F & $\begin{array}{l}\text { Anlamlılık } \\
\text { Düzeyi (p) }\end{array}$ \\
\hline Akademik başarı ön test & 21.2 & 1 & 21.2 & 2.01 & .17 \\
\hline Grup (Deney ve Kontrol) & 0.80 & 1 & 0.79 & 0.08 & .79 \\
\hline
\end{tabular}




\begin{tabular}{|l|l|l|l|l|}
\hline Hata & 317 & 30 & 10.6 & \multirow{2}{*}{} \\
\cline { 1 - 3 } Toplam & 338 & 32 & & \\
\cline { 1 - 2 }$>.05$ &
\end{tabular}

Tablo 7 incelendiğinde, deney ve kontrol grubunun ön test puanlarına göre düzeltilmiş “Akademik Başarı Testi" son testi ortalamaları arasında manidar bir farkın olmadığı bulunmuştur $[\mathrm{F}(1,30)=0.08, \mathrm{p}>.05] . \mathrm{Bu}$ bulguya göre geleneksel ölçme ve değerlendirme yaklaşımlarını destekleyici nitelikteki tamamlayıcı ölçme ve değerlendirme yaklaşımlarının kullanıldığı deney grubu öğrencilerinin akademik başarı düzeltilmiş son test puanları ile sadece geleneksel ölçme ve değerlendirme yaklaşımlarının uygulandığı kontrol grubu öğrencilerinin akademik başarı düzeltilmiş son test puanları arasında manidar bir farkın olmayışı, tamamlayıcı ölçme ve değerlendirme uygulamalarının akademik başarı üzerinde manidar etkisinin olmadığını göstermektedir.

\section{Sonuç ve Tartışma}

$\mathrm{Bu}$ bölümde, "Işılk" ünitesinde tamamlayıcı ölçme ve değerlendirme yaklaşımlarının kullanılmasının öğrencilerin tutumuna ve başarısına etkisi araştırılarak elde edilen sonuçlar ve sonuçlara göre oluşturulan önerilere yer verilmiştir.

Tamamlayıcı ölçme ve değerlendirme yaklaşımlarının derse yönelik olumlu etkilerinin olduğunu gösteren çalışmalar (Mihladız 2007, 58-95; Wen \& Tsai 2008, 57-64; Alsadaawi 2008, 513; Cihanoğlu 2008, 65-162; Bahçeci 2009, 171-176; Çalışkan 2009, 38-132; Karakuş 2009, 126-139; Gömleksiz \& Koç 2010, 81-93; Olğun 2011, 127-173) olduğu gibi, tamamlayıcı ölçme ve değerlendirme yaklaşımlarının derse yönelik tutuma bir etkisinin olmadığını belirten çalışmalar da (Olina \& Sullivan 2002, 9-19; Coşkun 2007, 37-65; Buluş-Kırıkkaya \& Vurkaya 2011, 988-994) mevcuttur. Değerlendirme sürecinde, geleneksel ölçme ve değerlendirme ile tamamlayıcı ölçme ve değerlendirme yaklaşımlarının birlikte uygulandığı deney grubu öğrencileri ile sadece geleneksel ölçme ve değerlendirmenin uygulandığı kontrol grubu öğrencilerinin fen bilimleri dersine yönelik tutumları arasında, istatiksel olarak manidar bir farkın olmadığ tespit edilmiştir. Tamamlayıcı ölçme ve değerlendirme uygulamalarının öğrencilerin derse yönelik tutum puanları arasında istatiksel olarak manidar bir farkın çıkmamasına; derslerin aynı müfredattan yararlanılarak işlenmesi, iki grubun az kişiden oluşması ve dolayısıyla araştırmacının her bireye ulaşması ve onlarla yakından ilgilenmesi, iki grubun tutum ortalama puanlarının yüksek olması, katılımcıların ilk kez böyle bir çalışma yapıyor olmaları, bazı öğrencilerin sorumsuz davranışlar sergilemesi, uygulamanın özel okulda gerçekleşmesi ve buna bağlı olarak sosyal çevrenin aynı oluşu, öğrencilerin birbirine karşı tutumları, başarı motivasyonu, uygulama süresinin beş haftayla sınırlı olması ve tutum gibi davranış değiştirmeye yönelik uygulamaların uzun zaman gerektirmesi gibi etkenlerin sebep olduğu birçok bilimsel çalışmada belirtilmektedir (Çepni et al. 2006, 202-203; Coşkun 2007, 37-65; Serin \& Mohammadzadeh 2008, 69-71; Alrehaly 2011, 5-6).

Tutum duyuşsal alan kapsamında incelendiği için Friedman, Cox ve Maher'in (2008, 587601) yaptığı bir çalışmada, katılımcıların akranlarını sık sık değerlendirmesi ve geri bildirimde bulunması akranlarının motivasyonları gibi duyuşsal özelliklerinin gelişimine etki etmediği ifade edilmektedir. Öğrencilere hiçbir değerlendirmenin uygulanmaması, onların kendilerini bask1 altında hissetmemelerine ve dolayısıyla rahat bir eğitim öğretim geçirmelerine neden olabilir. Değerlendirme yöntemleri eğitim öğretimin ayrılmaz bir parçasıdır fakat ölçme ve değerlendirme ile ilgili yapılan deneysel bir çalışma incelendiğinde hiçbir değerlendirme yönteminin uygulanmadığı grubun tutum puanları, geleneksel ölçme ve değerlendirme yaklaşımlarının uygulandığı grup ile tamamlayıcı ölçme değerlendirme yaklaşımlarının uygulandığı grup 
öğrencilerinin tutum puanlarından daha yüksek olduğu tespit edilmiştir. Bu sonuç, hiçbir değerlendirme yönteminin uygulanmamasının öğrencilerin derse yönelik tutumlarını pozitif yönde etkilediğini göstermektedir (Olina \& Sullivan 2002, 17).

Okan (2005, 43-87), tamamlayıcı ölçme ve değerlendirme yaklaşımları ile duyuşsal özelliklerin geleneksel ölçme ve değerlendirme yaklaşımlarına göre daha kolay ölçülebilir olduğunu ifade etmektedir. Buna ilaveten tamamlayıcı değerlendirme yaklaşımları ile öğrenci, öğrenmeleri üzerine sorumluluk alır. Öğrencilere, öğretmenleri ve arkadaşları tarafından geri bildirimler verilerek öğrenci desteklenir. Öğrenci akranları tarafından değerlendirileceğini bilir. Aynı zamanda kendi öz değerlendirmesini de yapacağı için duyuşsal özellikleri gelişebilir (Alsadaawi 2008, 5-13; Wen \& Tsai 2008, 57-64). Araştırma sonuçlarına bakıldığında ise tamamlayıcı ölçme ve değerlendirme yaklaşımlarının tutum üzerine istatiksel olarak manidar olmadığı bulunsa da, öğrenciler üzerinde pozitif bir etki yarattığı görülmektedir.

Tamamlayıcı ölçme ve değerlendirme yaklaşımlarının akademik başarı üzerine bir etkisinin olmadığını belirten çalışmalar (El-Koumy 2001, 11-16; Olina \& Sullivan 2002, 9-19; Bahçeci \& Kuru 2006, 145-159; Coşkun 2007, 37-65; Uysal 2008, 35-65; Erdin 2010, 30-57; Gömleksiz \& Koç 2010, 81-93) olduğu gibi, başarıyı arttırdığını ifade eden çalışmalar da (Mıhladız 2007, 5895; Orhan 2007, 66-117; Alsadaawi 2008, 5-13; Cihanoğlu 2008, 65-162; Güven \& Aydoğdu 2009, 116-120; Taşdemir et al. 2009, 53-62; Yalaki 2010, 227-235; El-Koumy 2010, 11-16; Chang \& Wu 2011, 164-167; Moheidat \& Baniabdelrahman 2011, 58-67; Olğun 2011, 127-173) mevcuttur.

Değerlendirme sürecinde geleneksel ölçme ve değerlendirme ile tamamlayıcı ölçme ve değerlendirme yaklaşımlarının birlikte uygulandığı deney grubundaki öğrencilerin "Işslk" ünitesindeki akademik başarıları ile sadece geleneksel ölçme ve değerlendirmenin uygulandığı kontrol grubu öğrencilerinin akademik başarıları arasında istatiksel olarak manidar bir farkın olmadığı belirlenmiştir. Tamamlayıcı ölçme ve değerlendirme yaklaşımlarının katılımcıların akademik başarı puanları arasında istatiksel olarak farkın çıkmamasına; uygulanan iki öğretim yönteminin öğrenciyi aktif kılması, uygulama okulunun özel okul olması ve velilerin tamamına yakınının öğrenciler ile yakından ilgilenmesi ve buna bağlı olarak tüm öğrencilerde başarma isteğinin olması gibi etkenlerin sebep olduğu düşünülmektedir. Ayrıca, başarı ile ilişkili olarak; bilgisayar kullanımı, öğrencinin başarı ve başarısızlık algısı, kaygı, öz yeterlik, tutum ile öğrenme süreçlerini planlama gibi faktörlerin başarıyı etkileyen diğer etmenlerin olduğu da bilinmektedir (Albayrak 2009, 12-16; Eren 2011, 27).

Öğrencilerin akademik başarılarının arttırılması için tamamlayıcı ölçme ve değerlendirmelerinin en baştan ve daha uzun etkileşimlerle uygulanmasının daha etkili olabileceği düşünülmektedir (Erdin 2010, 30-57). Bununla birlikte öğrenciler hakkında kesin kararlar verebilmek için tamamlayıcı ölçme ve değerlendirme yaklaşımlarının yanında geleneksel kağıt-kalem testlerinden de yararlanılmasına ihtiyaç duyulmaktadır (Çalışkan 2009, 38-132).

Öğrencilerin eğitim öğretim sürecinde edindiği bilgileri günlük hayata aktarması söz konusu olduğunda başarı anlamlı olacaktır. Bilgilerin günlük hayata aktarılamaması ezberci bir eğitim anlayışından geçer. Yapılandırmacı eğitim anlayışının hakim olduğu günümüzde bilgilerin günlük hayata aktarılmasına katkı sağlayan değerlendirme yaklaşımı tamamlayıcı ölçme ve değerlendirme yaklaşımıdır (Bahçeci \& Kuru 2006, 157).

\section{Öneriler}

Araştırmacılara, bu çalışmadan yola çıkarak, farklı sosyo-ekonomik düzey ve okulların bulunduğu çevre (köy, şehir veya kasaba vb.) gibi değişkenlerin araştırıldığı çalışmalar önerilebilir. Bu 
araştırmanın sonuçlarının tamamlayıcı ölçme ve değerlendirme yaklaşımlarından akran değerlendirme, öz değerlendirme, grup değerlendirme ile sınırlı olduğu düşünülerek benzer çalışmalar diğer tamamlayıcı ölçme ve değerlendirme yaklaşımları kullanılarak yapılabilir. Tamamlayıcı ölçme ve değerlendirme ile ilgili yapılan çalışmaların daha uzun zamanlarda sürdürülmesi önerilebilir.

\section{KAYNAKÇA}

Albayrak A. (2009). PISA 2006 Sınavı Sonuçlarına Göre Türkiye'deki Öğrencilerin Fen Başarılarını Etkileyen Bazı Faktörler. Yayımlanmış Yüksek Lisans Tezi. Hacettepe Üniversitesi, Ankara 2009.

Alrehaly E. D. (2011). "Parental Attitudes and the Effects of Ethnicity: How They Influence Children's Attitudes Toward Science Education”. ERIC doküman no: ED515978 Kaynak: ERIC veri tabanından alınmıştır (2012, March 13).

Alsadaawi A. (2008). "An Investigation of Performance-Based Assessment in Science in Saudi Primary". The Annual Conference of the International Association for Educational Assessment (September $7^{\text {th }}$ $12^{\text {th }}$ 2008). Cambridge.

Anderson R. S. (1998). "Why Talk About Different Ways to Grade? The Shift From Traditional Assessment to Alternative Assessment". New Directions for Teaching and Learning 74 (1998) 5-16.

Arslan-Cansever B. (2009). "Avrupa Birliği Eğitim Politikaları ve Türkiye'nin Bu Politikalara Uyum Sürecinin Değerlendirilmesi”. International Online Journal of Educational Sciences I/1 (2009) 222232.

Aşkar P., Paykoç F., Korkut F., Olkun S., Yangın B. \& Çakıroğlu J. (2005). "Yeni Öğretim Programlarını İnceleme ve Değerlendirme Raporu”. Kaynak: http://ilkogretim-online.org.tr/vol5say1/yenimu fredat_raporu[1].pdf. Erişim Tarihi: 20 Aralık 2011.

Bahçeci D. \& Kuru M. (2006). "Portfolyo Değerlendirmenin İnsan İskelet Sistemi Konusunda Öğrenci Akademik Başarısı Üzerine Etkisi”. Ahi Evran Üniversitesi Kırşehir Eğitim Fakültesi Dergisi 7/2 (2006) 145-162.

Baniabdelrahman A. A. (2010). "The Effect of the Use of Self-Assessment on EFL Students Performance in Reading Comprehension in English". The Electronic Journal for English as a Second Language 14/2 (2010) 3-22.

Bloom B. S. (1979). Inssan Nitelikleri ve Okulda Öğrenme. Çev. D. A. Özçelik. Ankara 1979.

Britton T. (2011). "Using Formative and Alternative Assessments to Support Instruction and Measure Student Learning". Science Scope 34/5 (2011) 16-21.

Buluş-Kırıkkaya E. \& Vurkaya G. (2011). "Alternatif Değerlendirme Etkinliklerinin Fen ve Teknoloji Dersinde Kullanılmasının Öğrencilerin Akademik Başarıları ve Tutumlarına Etkisi”. Kuram ve Uygulamada Eğitim Bilimleri 11/2 (2011) 985-1004.

Büyüköztürk Ş. (2010). Sosyal Bilimler İçin Veri Analiz El Kitabı. Ankara 2010.

Büyüköztürk Ş., Kılıç-Çakmak E., Akgün Ö. E., Karadeniz Ş. \& Demirel F. (2010). Bilimsel Araştırma Yöntemleri. Ankara 2010.

Chang C. C. \& Wu M. F. (2011). "Comparisons of Reliability and Validity Between TeacherAssessment, Student Self-Assessment, and Peer-Assessment in a Web-Based Portfolio Assessment Environment". Joumal of Educational Media \& Library Sciences 49/1 (2011) 135-170.

Choi K., Lee H., Shin N., Kim S. W. \& Krajcik J. (2011). "Re-Conceptualization of Scientific Literacy in South Korea for the $21^{\text {st }}$ Century". Journal of Research in Science Teaching 48/6 (2011) 670-697.

Cihanoğlu M. O. (2008). Alternatif Değerlendirme Yaklaşımlarından Öz ve Akran Değerlendirmenin İsbirlikli Öğrenme Ortamlarında Akademik Başarı, Tutum ve Kalıcllı̆ga Etkileri. Yayımlanmış Doktora Tezi. Dokuz Eylül Üniversitesi, İzmir 2008.

Coşkun G. (2007). Performansa Dayalı Durum Belirlemenin Öğrencilerin Matematik Dersindeki Özyeterlik Algısına, Tutumuna ve Başarısına Etkisi. Yayımlanmış Yüksek Lisans Tezi. Hacettepe Üniversitesi, Ankara 2007. 
Çalışkan İ. (2009). Fen ve Teknoloji Öğretmen Adaylarının Tamamlayıcı Ölçme ve Değerlendirme Yaklaşımlarını Kullanma Becerileri ile Fen ve Teknoloji Öğretmen ve Öğretmen Adaylarının Bu Yaklaşımlarla Illgili Görüşleri Hakkında Durum Belirleme Çalı̧̧ması Ankara İli ve Hacettepe Üniversitesi Örneği. Yayımlanmış Doktora Tezi. Hacettepe Üniversitesi, Ankara 2009.

Çepni S., Ayvacı Ş. H. \& Bacanak A. (2009). Bilim Teknoloji Toplum ve Sosyal Değişim. Trabzon 2009.

Çepni S., Taş E. \& Köse S. (2006). "The Effects of Computer-Assisted Material on Students' Cognitive Levels, Misconceptions and Attitudes Towards Science". Computers and Education 46/2 (2006)192205.

Çiftçi S. (2010). "İlköğretim Birinci Kademe 4. ve 5. Sınıf Öğretmenlerinin Performans Görevlerine İlişkin Görüşleri”. İlköğretim Online Dergisi 9/3 (2010) 934-951.

Demirel Ö. (2011). Kuramdan Uygulamaya Eğitimde Program Gelişstirme. Ankara 2011.

El-Koumy A. S. A. K. (2001). "Effects of Student Self-Assessment on Knowledge Achievement and Academic Thinking". ERIC doküman no: ED452731. Kaynak: ERIC veri tabanından alınmıştır (2014, 9 October).

El-Koumy A. S. A. K. (2008). "Student Self-Assessment in Higher Education: Alone or Plus?". The CPLA Conference (October $29^{\text {th }}-30^{\text {th }} 2010$ ). Lübnan.

Erdin Y. (2010). Tamamlayıcı Ölçme ve Değerlendirme Yaklaşımının Verimli Çalışma Alış̧kanlıkları ve Öğrenmenin Kalıcllığı Üzerine Etkisi. Yayımlanmış Yüksek Lisans Tezi. Hacettepe Üniversitesi, Ankara 2010.

Eren O. (2011). İlköğretim 6., 7. ve 8. Sinıf Öğrencilerinin Ders Çalışma Alışkanlıkları ile Fen ve Teknoloji Dersi Akademik Başarıları Arasındaki İlişki. Yayımlanmış Yüksek Lisans Tezi. Ankara Üniversitesi, Ankara 2011.

Friedman B. A., Cox P. L. \& Maher L. E. (2008). “An Expectancy Theory Motivation Approach to Peer Assessment". Journal of Management Education 32/5 (2008) 580-612.

Gelbal S. \& Kelecioğlu H. (2007). "Öğretmenlerin Ölçme ve Değerlendirme Yöntemleri Hakkındaki Yeterlik Algıları ve Karşılaştıkları Sorunlar”. Hacettepe Üniversitesi Eğitim Fakültesi Dergisi 33 (2007) 135-145.

Gömleksiz M. N. \& Koç A. (2010). "Bilgisayar Okuryazarlığı Becerisi Ediniminde e-Portfolyo Sürecinin Öğrenen Performansına ve Tutumlarına Etkisi”. Erzincan Eğitim Fakültesi Dergisi 12/2 (2010) 75-96.

Gültekin M., Karadă̆ R. \& Yılmaz F. (2007). "Yapılandırmacılık ve Öğretim Uygulamalarına Yansımaları". Anadolu Üniversitesi Sosyal Bilimler Dergisi 7/2 (2007) 503-528.

Güven E. \& Aydoğdu M. (2009). "Portfolyonun 6. Sinıf Fen ve Teknoloji Dersi Vücudumuzda Sistemler Ünitesi'nde Başarı ve Kalıcılığa Etkisi”. Türk Fen Eğitimi Dergisi 6/2 (2009) 115-128.

MEB. (2009). Hayat Boyu Öğrenme Strateji Belgesi. Ankara.

Karakuş F. (2009). "Sosyal Bilgiler Öğretiminde Oluşturmacı Öğrenme ve Otantik Değerlendirme Yaklaşımlarının Öğrencilerin Sosyal Bilgiler Dersine Yönelik Tutumlarına ve Kalıcılığa Etkisi”. Çukurova Üniversitesi Eğitim Fakültesi Dergisi 3/36 (2009) 124-141.

Kavaliauskienė G., Kaminskienè L. \& Anusienè L. (2007). "The Challenges for Esp Learners: Alternative Assessment of Performance and Usefulness of Class Activities". Socialinis Darbas 6/1 (2007) 134-144.

Korkmaz H. \& Kaptan F. (2002) "Fen Eğitiminde Öğrencilerin Gelişimini Değerlendirmek İçin Portfolyo Kullanımı Üzerine Bir İnceleme”. Hacettepe Üniversitesi Eğitim Fakültesi Dergisi 23 (2002) 167-176.

Lawrenz F., Huffman D. \& Welch W. (2001). "The Science Achievement of Various Subgroups on Alternative Assessment Formats". Science Education 85/3 (2001) 279-290.

Lederman N. G., Abd-El-Khalick F., Bell R. L. \& Schwartz R. S. (2002). "Views of Nature of Science Questionnaire: Toward Valid and Meaningful Assessment of Learners' Conceptions of Nature of Science". Journal of Research in Science Teaching 39/6 (2002) 497-521.

MEB. (2013). Milli Ĕgitim Bakanlı̆̆ı İlköğretim Fen Bilimleri Dersi Öğretim Programı ve Kılavuzu 3, 4, 5, 6, 7 ve 8. Sinuflar. Ankara.

Mıhladız G. (2007). İlköğretim Fen Bilgisi Öğretiminde Portfolyo Uygulamasının Öğrencilerin Akademik Başarılarına ve Derse Yönelik Tutumlarına Etkisi. Yayımlanmış Yüksek Lisans Tezi. Muğla 
Üniversitesi, Muğla 2007.

Moheidat A. S. \& Baniabdelrahman A. A. (2011). "The Impact of Omani Twelfth-Grade Students' SelfAssessment on Their Performance in Reading in English". Asian EFL Journal 13/1 (2011) 48-84.

Oğuz M. (2002). Illköğretim Fen Bilgisi Dersinde Yaratıcı Problem Çözme Yönteminin Başariya ve Tutuma Etkisi. Yayımlanmamış Yüksek Lisans Tezi. Hacettepe Üniversitesi, Ankara 2002.

Olğun M. (2011). Ilköğretim 4. Sinıf Fen ve Teknoloji Dersinde Öz ve Akran Değerlendirme Uygulamalarının Yer Aldı̆̆ İşbirlikli Öğrenme Yönteminin Öğrencilerin Başarı, Tutum ve Biliş̧üstü Becerilerine Etkisi. Yayımlanmıș Yüksek Lisans Tezi. Dokuz Eylül Üniversitesi, İzmir 2011.

Olina Z. \& Sullivan H. J. (2002). "Effects of Teacher and Self-Assessment on Student Performance". ERIC doküman no: ED463329 Kaynak: ERIC veri tabanından alınmıştır (07 April, 2011).

Orhan A. T. (2007). Fen Eğitiminde Alternatif Ölçme ve Değerlendirme Yöntemlerinin İlköğretim Öğretmen Adayı, Öğretmen ve Öğrenci Boyutu Dikkate Alınarak Incelenmesi. Yayımlanmış Doktora Tezi. Gazi Üniversitesi, Ankara 2007.

Perkins D. (1999). "The Many Faces of Constructivism". Educational Leadership 57/3 (1999) 6-11.

Poon W. Y., McNaught C., Lam P. \& Kwan H. S. (2009). "Improving Assessment Methods in University Science Education with Negotiated Self- and Peer-Assessment". Assessment in Education: Principles, Policy \& Practice 16/3 (2009) 331-346.

Senemoğlu N. (2011). Gelişim, Öğrenme ve Öğretim. Ankara 2011.

Serin O. \& Mohammadzadeh B. (2008). "The Relationship Between Primary School Students' Attitudes Towards Science and Their Science Achievement (Sampling: İzmir)". Cypriot Journal of Educational Sciences 3/2 (2008) 68-75.

Tan M. \& Temiz B. K. (2003). "Fen Öğretiminde Bilimsel Süreç Becerilerinin Yeri ve Önemi". Pamukkale Üniversitesi Eğitim Fakültesi Dergisi 13/1 (2003) 89-101.

Taşdemir M., Taşdemir A. \& Yıldırım K. (2009). "Influence of Portfolio Evaluation in Cooperative Learning on Student Success". Eğitimde Kuram ve Uygulama 5/1 (2009) 53-66.

Uysal K. (2008). Öğrencilerin Ölçme Değerlendirme Sürecine Katılması: Akran Değerlendirme ve Öz Değerlendirme. Yayımlanmış Yüksek Lisans Tezi. Abant İzzet Baysal Üniversitesi, Bolu 2008.

Uzun S., Bütüner S. Ö. \& Yiğit N. (2010). "1999-2007 TIMSS Fen Bilimleri ve Matematik Sonuçlarının Karşılaştırılması: Sınavda En Başarılı İlk Beş Ülke-Türkiye Örneği”. İlköğretim Online 9/3 (2010) 1174-1188.

Ün-Açıkgöz K. (2011). Aktif Öğrenme. İstanbul 2011.

Wen M. L. \& Tsai C. C. (2008). "Online Peer Assessment in an Inservice Science and Mathematics Teacher Education Course". Teaching in Higher Education 13/1 (2008) 55-67.

Yalaki Y. (2010). "Simple Formative Assessment, High Learning Gains in College General Chemistry". Eurasian Journal of Educational Research 40 (2010) 223-240.

Yıldırım A. (2006). Illköğretim Okulları Íkinci Kademede Ölçme ve Değerlendirmeye İlişsin Görüşler (Diyarbakır ve Elazığ Ili Örneği). Yayımlanmış Yüksek Lisans Tezi. Fırat Üniversitesi, Elazığ 2006.

Yıldırım F. \& Karakoç-Öztürk B. (2009). "Türkçe Dersi Öğretim Programının Ölçme Değerlendirme Ögesi Hakkında Öğretmen Görüşleri”. Çukurova Üniversitesi Eğitim Fakültesi Dergisi $3 / 37$ (2009) 92-108. 